\title{
Effect of Metal Oxide Nanoparticles on the Chemical Speciation of Heavy Metals and Micronutrient Bioavailability in Paddy Soil
}

\author{
Wei Zhang ${ }^{1,2}{ }^{\oplus}$, Jinghua Long ${ }^{2}$, Jie Li ${ }^{3}$, Meng Zhang ${ }^{1}$, Xingyin $\mathrm{Ye}^{1}{ }^{1}$, Wenjing Chang ${ }^{1}$ and \\ Hui Zeng ${ }^{1,4, *}$ \\ 1 School of Urban Planning and Design, Peking University Shenzhen Graduate School, Shenzhen 518055, \\ China; zhangdaw007@heuet.edu.cn (W.Z.); zhangmeng@pkusz.edu.cn (M.Z.); yexingyin@pku.edu.cn (X.Y.); \\ changwj@pkusz.edu.cn (W.C.) \\ 2 School of Public Administration, Hebei University of Economics and Business, Shijiazhuang 050061, China; \\ longjh_jm@heuet.edu.cn \\ 3 College of Land and Environment, Shenyang Agricultural University, Shenyang 110866, China; \\ lijie@syau.edu.cn \\ 4 College of Urban and Environmental Sciences, Peking University, Beijing 100871, China \\ * Correspondence: zengh@pkusz.edu.cn; Tel.: +86-0755-26035585
}

Received: 10 February 2020; Accepted: 3 April 2020; Published: 5 April 2020

\begin{abstract}
The effects of engineered nanoparticles (ENPs) on heavy metal fate and biotoxicity in farmland soil are mostly unknown. A flooding-drying simulation experiment was conducted to study the effects of three typical metal oxide nanoparticles $\left(\mathrm{TiO}_{2}-\mathrm{NPs}, \mathrm{ZnO}-\mathrm{NPs}\right.$ and $\left.\mathrm{CuO}-\mathrm{NPs}\right)$ on the chemical speciation of heavy metals and micronutrient bioavailability in paddy soil. The results showed that the addition of $\mathrm{ZnO}-\mathrm{NPs}$ and $\mathrm{CuO}-\mathrm{NPs}$ caused significant increases in soil $\mathrm{pH}$, Eh and EC after a 90-d flooding-drying process. ZnO-NPs and CuO-NPs addition caused clearly increase in the $\mathrm{Zn}$ and $\mathrm{Cu}$ concentrations in the acid-soluble fraction, Fe/Mn oxides-bound fraction and organic-bound fraction, leading to higher bioavailability in the soil. DTPA-extractable $\mathrm{Zn}$ and $\mathrm{Cu}$ increased to $184.6 \mathrm{mg} \mathrm{kg}^{-1}$ and $145.3 \mathrm{mg} \mathrm{kg}^{-1}$ in the maximum $\mathrm{ZnO}-\mathrm{NPs}$ and CuO-NPs concentration treatments $\left(500 \mathrm{mg} \mathrm{kg}^{-1}\right.$ ). $\mathrm{TiO}_{2}-\mathrm{NPs}$ promoted the transformation of $\mathrm{Mn}$ from a $\mathrm{Fe} / \mathrm{Mn}$ oxides-bound fraction to an acid-soluble fraction. Soil $\mathrm{Cd}$ bioavailability obviously decreased in the $\mathrm{TiO}_{2}-\mathrm{NPs}$ treatment but increased in the $\mathrm{ZnO}-\mathrm{NPs}$ and $\mathrm{CuO}-\mathrm{NPs}$ treatments.
\end{abstract}

Keywords: metal oxide nanoparticles; heavy metal; bioavailability; paddy soil

\section{Introduction}

With the wide use of nanomaterials, large numbers of engineered nanoparticles (ENPs) are discharged into the water and soil system [1,2]. $\mathrm{TiO}_{2}-\mathrm{NPs}, \mathrm{ZnO}-\mathrm{NPs}$ and $\mathrm{CuO}-\mathrm{NPs}$ are common metal oxide nanoparticles (MNPs) used in plant growth, cosmetics, surface coating and sunscreens, etc., and the biotoxicity and the environmental risk of these metal oxide nanoparticles has caused extensive concern in recent years [3,4]. For example, $\mathrm{CuO}$ nanoparticles caused a significant decrease in rice seed germination percentage [5], and $1000 \mathrm{mg} \mathrm{L}-1 \mathrm{ZnO}-\mathrm{NPs}$ could reduce the root length of corn and cucumber [6]. The biotoxicity of nanoparticles depends on its particle size, surface charge and concentration [7].

Due to the special surface properties of nanoparticles, they can influence the migration and bioavailability of co-existing contaminants in the water and soil environment. [2,8-10]. For example, Shrestha et al. (2015) found that multiwalled carbon nanotubes (MWCNTs) significantly reduced the toxicity and bioavailability of polycyclic aromatic hydrocarbons (PAHs) in the soil microbial community, 
and the effects were dependent on the soil organic matter content [11]. Zero-valent iron nanoparticles (nZVI), often used in water and soil pollution remediation, could effectively reduce contaminants' bioavailability $[12,13]$. Graphene oxide (GO) could promote the transformation of arsenic (As) from $\mathrm{As}(\mathrm{V})$ to high-toxicity As(III) in soil, and significantly influence the morphological and biochemical characteristics of rice [14]. $\mathrm{TiO}_{2}-\mathrm{NPs}$ significantly reduced the toxic effects of tetracycline on rice in terms of its fresh biomass and levels of antioxidant enzymes [15]. Most of the studies about the effect of nanoparticles on heavy metals behaviour were conducted in hydroponic conditions, and only a few were conducted in soil conditions [4,16-18].

MNPs would dissolve and release metal ions after entering the aquatic system or under soil environment. For example, Franklin et al. demonstrated that ZnO-NPs rapidly dissolved in a freshwater medium ( $\mathrm{pH}$ 7.6) and a buffer solution $\left(0.01 \mathrm{M} \mathrm{Ca}\left(\mathrm{NO}_{3}\right)_{2}, \mathrm{pH} 7.5\right)$, and the concentrations of $\mathrm{Zn}^{2+}$ reached $6 \mathrm{mg} \cdot \mathrm{L}^{-1}$ and $16 \mathrm{mg} \cdot \mathrm{L}^{-1}$ in $6 \mathrm{~h}$ and $72 \mathrm{~h}$, respectively [19]. Some studies concluded that the toxicity of CuO-NPs depends on its solubility in soil $[20,21]$. Addition of $500 \mathrm{mg} \mathrm{kg}$ CuO-NPs caused the labile $\mathrm{Cu}$ in the soil to increase by $206 \mathrm{mg} \mathrm{kg}$ after a 42 day pot experiment [22]. At present, the connection between MNP dissolution, the resulting dose of metal ions, and changes in the chemical speciation of heavy metals and its influence on soil micronutrient bioavailability have not been well elucidated due to a lack of appropriate characterization of the dissolution of the NPs in soil. Moreover, due to the complexity of soil media, it is hard to explain the mechanism of various phenomena in soil experiments.

The current study focused on the environmental behaviour of MNPs in paddy soil. A flooding-drying simulation experiment was conducted to study the effect of three typical metal oxide nanoparticles ( $\mathrm{TiO}_{2}$-NPs, $\mathrm{ZnO}-\mathrm{NPs}$ and $\mathrm{CuO}-\mathrm{NPs}$ ) on the chemical speciation of heavy metals and the micronutrient bioavailability in paddy soil. The results will further our understanding on the nanoparticles behaviour in soil and provide a scientific assessment for the agricultural ecological risk of engineered nanoparticles.

\section{Materials and Methods}

\subsection{Soil Characteristics}

The paddy soil used in this research was sampled from Huizhou, Guangdong Province, China. Soil samples were air dried and sieved to less than $2 \mathrm{~mm}$. The contents of organic matter (OM) and cation exchange capacity (CEC) were $24.5 \mathrm{~g} \cdot \mathrm{kg}^{-1}$, and $8.50 \mathrm{cmol} \cdot \mathrm{kg}^{-1}$, respectively. The concentrations of $\mathrm{Fe}, \mathrm{Mn}, \mathrm{Cu}, \mathrm{Zn}$ and $\mathrm{Cd}$ in soil were $9.43 \mathrm{~g} \cdot \mathrm{kg}^{-1}, 92.7 \mathrm{mg} \cdot \mathrm{kg}^{-1}, 22.6 \mathrm{mg} \cdot \mathrm{kg}^{-1}, 56.7 \mathrm{mg} \cdot \mathrm{kg}^{-1}$ and $2.70 \mathrm{mg} \cdot \mathrm{kg}^{-1}$, respectively (supporting information (S1) Table S1).

\subsection{Nanoparticles Characteristics}

The metal oxide nanoparticles ( $\mathrm{TiO}_{2}-\mathrm{NPs}, \mathrm{ZnO}-\mathrm{NPs}$ and $\left.\mathrm{CuO}-\mathrm{NPs}\right)$ used in this research were purchased from Nanjing XFNANO Materials Tech Co., Ltd, (Nanjing, China), and the purity of the nanomaterials is above $99.9 \%$. The characterizations of nanoparticles were performed in the Key laboratory of nano-micro materials, Peking University Shenzhen Graduate School. The size of the metal oxidize nanoparticles was detected by a field emission scanning electron microscope (ZEISS SUPRA ${ }^{\circledR}$ 55, Carl Zeiss, Jena, Germany), and the specific surface area was detected by an Accelerated Surface Area and Porosimetry System (ASAP 2020 HD88, Micromeritics, Atlanta, GA, USA). The diameter size of these MNPs in the range of $20-40 \mathrm{~nm}$. The specific surface areas of the $\mathrm{TiO}_{2}-\mathrm{NPs}$, ZnO-NPs and CuO-NPs were $77.4 \mathrm{~m}^{2} \cdot \mathrm{g}^{-1}, 21.5 \mathrm{~m}^{2} \cdot \mathrm{g}^{-1}$ and $131 \mathrm{~m}^{2} \cdot \mathrm{g}^{-1}$, respectively.

\subsection{Experimental Design}

Three different concentrations (50, 100 and $500 \mathrm{mg} \mathrm{kg}$ ) of MNPs $\left(\mathrm{TiO}_{2}-\mathrm{NPs}, \mathrm{ZnO}-\mathrm{NPs}\right.$ and CuO-NPs) were uniformly added into the soil ( $\mathrm{TiO}_{2}$-NPs: T50, T100, T500; ZnO-NPs: Z50, Z100, Z500; 
CuO-NPs: C50, C100, C500). The treatment with no nanoparticles added was set as the control (CK). Each treatment was conducted in triplicate.

Metal oxide nanoparticles powder $(0.05 \mathrm{~g}, 0.10 \mathrm{~g}$ and $0.50 \mathrm{~g})$ was finely dispersed with air-dried soil $(9.95 \mathrm{~g}, 9.90 \mathrm{~g}$ and $9.50 \mathrm{~g})$ in a ceramic plate, stir evenly. Next, the mixture was placed into a plastic bottle container $(2.5 \mathrm{~L})$ with $90 \mathrm{~g}$ air-dried soil sample, mixed thoroughly with a rotary agitator (YKZ-08) for $10 \mathrm{~min}$ ( $25 \mathrm{r} / \mathrm{min})$. Then, $900 \mathrm{~g}$ air-dried soil sample was added into the container, and shaken for $30 \mathrm{~min}$.

The $250 \mathrm{~g}$ mixed soil sample was placed into a bottle container $(10 \mathrm{~cm}$ diameter $\times 22 \mathrm{~cm}$ height), and $200 \mathrm{~mL}$ deionized water was added to the container. Soils were incubated for $90 \mathrm{~d}$ at $25^{\circ} \mathrm{C}$ in an incubator (SHP-250JB, Changzhou Putian instrument manufacturing Co., Ltd, Changzhou, China). The flooding-drying experiment simulated rice growth conditions, the start time was considered the seeding plant time, and the 30th, 60th and 90th $\mathrm{d}$ were considered the tillering stage, booting stage and heading stage, respectively. In the first 60-day period, the water layer depth was $3 \mathrm{~cm}$ above the soil surface, and we drew a line on the bottle surface; deionized water was added every day to achieve the flooding condition and keep the water depth stable. At the last 30-day period, the soil was treated in the drying-wetting condition alternately, and deionized water was supplemented every ten days [23]. After the 90-d experiment, the soil samples were collected, air dried and sieved to less than $2 \mathrm{~mm}$.

\subsection{Analytical Methods}

Soil $\mathrm{pH}$, electrical conductivity (EC) and soil redox potential (Eh) were measured by an ion analyser (Thermo-Orion, Beverly, MA, USA) with a combination electrode ( $\mathrm{pH}$ electrode, conductivity meter and oxidation reduction potential electrode) (9678BNWP, Thermo-Orion, Beverly, MA, USA) combined with a Super Ross vitreous reference electrode (800500U, Thermo-Orion, Beverly, MA, USA).

Soil samples were digested by a $\mathrm{HCl}-\mathrm{HNO}_{3}-\mathrm{HF}-\mathrm{HClO}_{4}$ mixed-acid digestion method. $0.5 \mathrm{~g}$ air-dried soil samples were digested with $35 \mathrm{ml}$ mixture of hydrochloric acid $(\mathrm{HCl})$, nitric acid $\left(\mathrm{HNO}_{3}\right)$, hydrofluoric acid (HF) and perchloric acid $\left(\mathrm{HClO}_{4}\right)(5 \mathrm{~mL}, 15 \mathrm{~mL}, 10 \mathrm{~mL}, 5 \mathrm{~mL})$ [2]. All the acid used in the digestion process was in a guaranteed reagent level (GR, 99.8\%), and the concentrations of the acids used in this digestion were $36 \%-38 \%, 65 \%-68 \%, \geq 40 \%$ and $70.0 \%-72.0 \%$ for hydrochloric acid $(\mathrm{HCl})$, nitric acid $\left(\mathrm{HNO}_{3}\right)$, hydrofluoric acid $(\mathrm{HF})$ and perchloric acid $\left(\mathrm{HClO}_{4}\right)$, respectively.

Improved BCR sequential extraction method was used to analyse the chemical speciation of heavy metals in soil, and the details of this method were described in Nemati et al. [24].

$\mathrm{CaCl}_{2}$ and diethylenetriaminepentaacetic acid solution (DTPA) extraction are two common methods used to predict the bioavailability of elements in soil. $\mathrm{CaCl}_{2}$-extractable is considered "readily available" to plants, and DTPA-extractable is considered "potentially available" fraction. In this study, the bioavailability of the micronutrients in the soil was extracted with calcium chloride solution $\left(\mathrm{CaCl}_{2}\right.$, $0.01 \mathrm{M})$ and (DTPA) [25]. Solutions was filtered with a Millipore filter $(0.45 \mu \mathrm{m})$, and the concentrations of the elements in the solution were determined by inductively coupled plasma mass spectrometry (Agilent 7700x ICP-MS, Agilent Technologies, Santa Clara, CA, USA). All samples were measured in triplicate, and the analytical error for selected elements was smaller than $3 \%$.

\subsection{Data Analysis}

Results were presented as mean \pm standard deviation (SD) of three independent experiments. All the experimental data was analysed by SPSS software (SPSS Statistics 20, IBM, Armonk, NY, USA), one-way ANOVA followed by the Tukey-HSD test was used to analyse the differences among various groups. $p<0.05$ indicated a significant difference. 


\section{Results and Discussion}

\subsection{Effect of MNPs Addition on Soil Properties}

The factors that influenced the heavy metal chemical speciation in the soil included $\mathrm{pH}$, redox potential (Eh), organic matter, cation exchange capacity (CEC), iron manganese oxides and microorganisms. The nanoparticles affected the physical and chemical properties, the components, and the microbial function and community structure of the soil [26-28], and they subsequently influenced the heavy metal transformation and bioavailability of the soil.

As shown in Figure 1a, the addition of ZnO-NPs and CuO-NPs caused significant $(p<0.05)$ increases in the values of soil pH after the 90-d flooding-drying process. Shi et al. (2018) found that $\mathrm{CuO}$ nanoparticles could significantly increase the soil $\mathrm{pH}$ values, which was consistent with our results [25]. Take CuO NPs as an example, after entering the soil, the following chemical reactions will occur:

$$
\begin{gathered}
\mathrm{CuO}+2 \mathrm{H}^{+} \leftrightarrow \mathrm{Cu}^{2+}+\mathrm{H}_{2} \mathrm{O} \\
\mathrm{CuO}+2 \mathrm{H}^{+} \leftrightarrow \mathrm{Cu}(\mathrm{HO})^{+}
\end{gathered}
$$

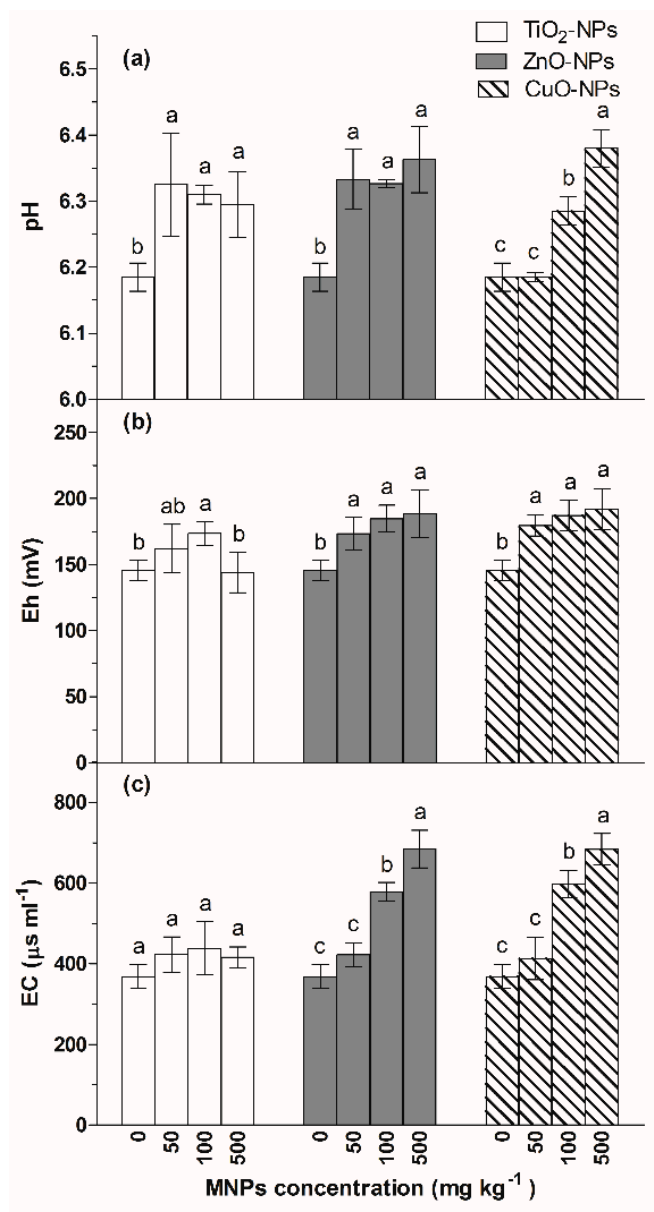

Figure 1. Changes in the values of soil $\mathrm{pH}(\mathbf{a})$, redox potential (Eh) (b) and electric conductivity (EC) (c) of the soil exposed to different MNPs. Different letters above each column indicate significant difference $(p<0.05)$ between various treatments in same group.

$\mathrm{CuO}$ could consume $\mathrm{H}^{+}$in soil solution, generate $\mathrm{Cu}^{2+}$ and $\mathrm{Cu}(\mathrm{HO})^{+}$, and consequently caused the increase in soil $\mathrm{pH}$ values. ZnO NPs has a similar reaction process in soil. Cullen et al. (2011) also observed that metal nanoparticles significantly increased the soil $\mathrm{pH}$ [29]. 
Soil redox potential is an important indicator in paddy soil. The changes of soil Eh depend on the properties and concentrations of oxidized and reductive substances in soil. During the flooding period, soil microorganisms consume the oxygen in the soil, and the air oxygen can not diffuse into the soil and generate reductive substances, thereby, causing the decrease of soil Eh. As shown in Figure 1b, the addition of ZnO-NPs and CuO-NPs caused a slight increase in soil Eh. For instance, the soil Eh increased by 20 30 $\mathrm{mV}$ in the $\mathrm{ZnO}-\mathrm{NPs}$ and CuO-NPs treated soil compared to that of the control. That was contrasted with Cullen et al.'s results, which demonstrated that nanoscale zerovalent iron decreased soil Eh. Frenk et al. (2013) found that a 1\% CuO-NPs addition could decrease the soil Eh, while, after a biocidal treatment, the addition of CuO-NPs could significantly increase the soil Eh. Their results demonstrated that CuO-NPs could influence soil Eh by both chemical and biological actions [30]. In the flooding condition, the influence of chemical action may be more obvious than biological action, and $\mathrm{CuO}-\mathrm{NPs}$ and $\mathrm{ZnO}-\mathrm{NPs}$ could consume reductive substance $\left(\mathrm{H}^{+}\right)$, causing the increase of soil Eh.

Soil electric conductivity (EC) was determined by the soil soluble salt content and affected plant nutrient uptake and growth. As shown in Figure 1c, higher concentrations of ZnO-NPs and CuO-NPs (500 and $100 \mathrm{mg} \cdot \mathrm{kg}^{-1}$ significantly $(p<0.05)$ increased soil EC values after the 90 -d flooding-drying process. The soil EC value increased from $368 \mu \mathrm{s} \cdot \mathrm{mL}^{-1}$ to 684 and $683.5 \mu \mathrm{s} \cdot \mathrm{mL}^{-1}$ in high concentrations (500 $\mathrm{mg} \cdot \mathrm{kg}^{-1}$ ) of ZnO-NPs and CuO-NPs treatment, respectively. The dissolution of CuO-NPs and $\mathrm{ZnO}-\mathrm{NPs}$ increased the $\mathrm{Zn}^{2+}$ and $\mathrm{Cu}^{2+}$ concentrations in the soil, also leading to the increase in soil EC. Previous studies have found that the addition of nanoscale CuO-NPs could significantly increase soil EC [31], partially supporting our observations. Due to the lower solubility of $\mathrm{TiO}_{2}-\mathrm{NPs}$, the amount of available $\mathrm{Ti}$ in the soil was not detected, and the soil $\mathrm{EC}$ for the $\mathrm{TiO}_{2}-\mathrm{NPs}$ treatment did not evidently change compared to those of the $\mathrm{ZnO}-\mathrm{NPs}$ and $\mathrm{CuO}-\mathrm{NPs}$.

\subsection{Effect of MNPs Addition on Heavy Metal Chemical Speciation}

The agglomeration of MNPs in soil medium caused inhomogeneous distribution of MNPs. The total content of $\mathrm{Cu}$ in the soils with $\mathrm{CuO}-\mathrm{NPs}^{\prime}$ addition and the $\mathrm{Zn}$ content in the soils with $\mathrm{ZnO}-\mathrm{NPs}$ ' addition were shown in Table S2. The recovery of $\mathrm{Cu}$ for $\mathrm{CuO}-\mathrm{NPs}$ addition soils in the range of $76 \%-81 \%$, and the recovery of $\mathrm{Zn}$ in the range of $80 \%-86 \%$.

After the 90-d flooding-drying process, Cd in the control soil was mostly in the form of the acid-soluble fraction, accounting for $75.4 \%$ of the total concentration; the $\mathrm{Fe} / \mathrm{Mn}$ oxide-bound fraction accounted for $16.6 \%$ of the total; the organic-bound fraction and residual accounted for $3 \%$ and $5 \%$, respectively (Figure 2). $\mathrm{Zn}$ and $\mathrm{Cu}$ in the control treatment were mostly in the form of residuals, accounting for $70.0 \%$ and $88.7 \%$ of the total concentration, respectively, and the acid-soluble fraction accounted for only $4.5 \%$ and $1.5 \%$, respectively. $\mathrm{Mn}$ in the control treatment mainly consists of the acid-soluble fraction and residual, accounting for $35.5 \%$ and $47.8 \%$ of total concentration, respectively.

\subsection{1. $\mathrm{TiO}_{2}-\mathrm{NPs}$}

As shown in Figure 2, the organic bound fraction and residual of the $\mathrm{Cu}, \mathrm{Zn}$ and $\mathrm{Cd}$ concentrations indicated no obvious effect from the $\mathrm{TiO}_{2}-\mathrm{NPs}$ treatment. The addition of $\mathrm{TiO}_{2}-\mathrm{NPs}$ significantly reduced the acid-soluble $\mathrm{Cu}$; however, there was no significant difference between different concentration treatments.

For the $\mathrm{TiO}_{2}-\mathrm{NPs}$ treatment, the acid-soluble $\mathrm{Mn}$ in the soil increased with the increase in $\mathrm{TiO}_{2}-\mathrm{NPs}$ concentration. The acid-soluble fraction of $\mathrm{Mn}$ in soil was much higher in T500 and T100 treatment than that in the control. The Fe/Mn oxides-bound fraction of Mn was obviously lower compared to that of the control. Results indicated that the addition of $\mathrm{TiO}_{2}-\mathrm{NPs}$ promoted the transformation of $\mathrm{Mn}$ from a Fe/Mn oxides-bound fraction to an acid-soluble fraction. The possible mechanisms may be related with electrons (electron-hole pairs), which generated on the surface of $\mathrm{TiO}_{2}-\mathrm{NPs}$, and the free electrons could promote the transformation of the $\mathrm{Fe}^{3+}, \mathrm{Mn}^{4+}$ and $\mathrm{Mn}^{3+}$ to $\mathrm{Fe}^{2+}$ and $\mathrm{Mn}^{2+}$. The released $\mathrm{Fe}^{2+}$ and $\mathrm{Mn}^{2+}$ were adsorbed on the surface of soil colloid and transformed into an acid-soluble fraction. 

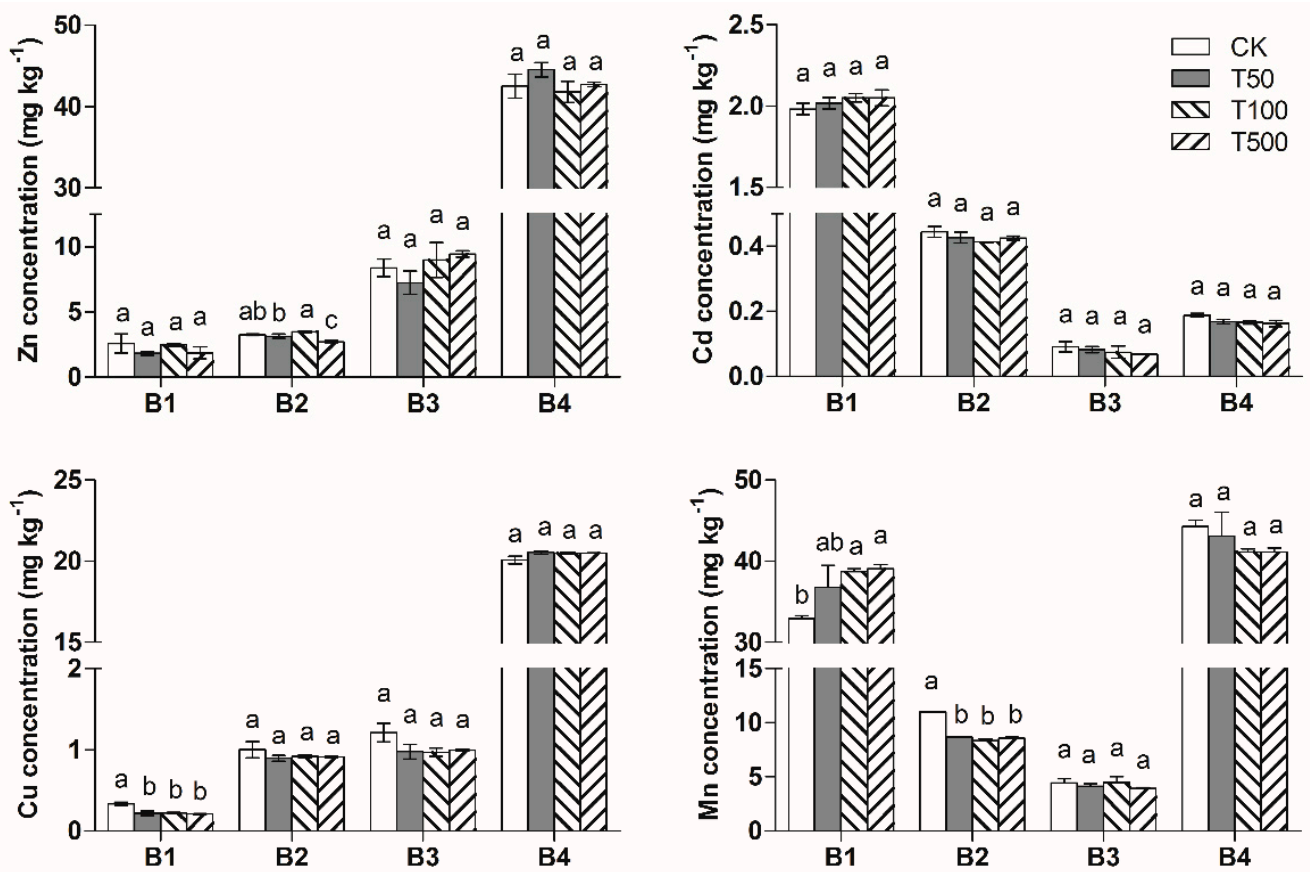

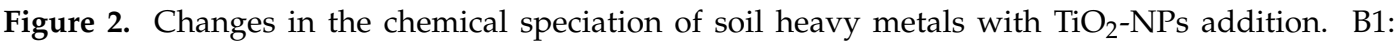
acid-soluble fraction; B2: Fe/Mn oxides-bound fraction; B3: organic-bound fraction; B4: residual fraction. Different letters above each column indicate significant difference $(p<0.05)$ between various treatments.

\subsection{2. $\mathrm{ZnO}-\mathrm{NPs}$}

For the $\mathrm{ZnO}-\mathrm{NPs}$ treatment, significant increases in the acid-soluble fraction, $\mathrm{Fe} / \mathrm{Mn}$ oxides-bound fraction and organic-bound fraction of the $\mathrm{Zn}$ concentration were observed (Figure 3). Different concentrations of $\mathrm{ZnO}-\mathrm{NPs}$ addition had no impact on the residual fraction of $\mathrm{Zn}$ in the soil. The acid-soluble fraction of $\mathrm{Zn}$ increased by $15.8,32.7$ and $215 \mathrm{mg} \cdot \mathrm{kg}^{-1}$ compared to the control treatment for Z50, Z100 and Z500, respectively. Compared with the control, the Fe/Mn oxides-bound fraction of $Z n$ in the $Z 50, Z 100$ and $Z 500$ treatments increased by $5.54,11.3$ and $50.4 \mathrm{mg} \cdot \mathrm{kg}^{-1}$, respectively, and the organic-bound fraction of $\mathrm{Zn}$ increased by $8.56,14.6$ and $64.7 \mathrm{mg} \cdot \mathrm{kg}^{-1}$, respectively.

This outcome revealed that $\mathrm{ZnO}-\mathrm{NPs}$ could dissolve in the soil and release ionic $\mathrm{Zn}$, and approximately $40 \% \sim 50 \%$ of the $\mathrm{Zn}$ ions existed in the acid-soluble fraction after the 90 -d experiment, $12 \% \sim 14 \%$ of the $\mathrm{Zn}$ ions existed in the Fe/Mn oxides-bound fraction, and $14 \% \sim 21 \%$ of the $\mathrm{Zn}$ ions existed in the organic-bound fraction.

For the $\mathrm{ZnO}-\mathrm{NPs}$ treatment, the acid-soluble $\mathrm{Cd}$ increased in response to the increase in the nanoparticle concentration. The acid-soluble fraction of $\mathrm{Cd}$ in the soil was much higher in the Z500 treatment than that in the $\mathrm{Z} 50$ and Z100 treatments. The Fe/Mn oxides-bound fraction of $\mathrm{Cd}$ in the $\mathrm{ZnO}-\mathrm{NPs}$ treatment was statistically $(p<0.05)$ significantly lower than that in the control treatment.

The addition of ZnO-NPs clearly increased the acid-soluble Mn concentrations and decreased the Fe/Mn oxides-bound fraction and organic fraction of the Mn concentrations. Normally, the iron and manganese oxides would dissolve in reductive conditions and undergo oxidative precipitation in oxidation conditions. In this research, the iron and manganese oxides in the soil were deoxidized into $\mathrm{Fe}^{2+}$ and $\mathrm{Mn}^{2+}$ under flooding conditions, and iron $\mathrm{Mn}$ was released into the surface water. During the drying process, the $\mathrm{Fe}^{2+}$ and $\mathrm{Mn}^{2+}$ would gradually oxidize and precipitate. Due to the oxidation time being relatively short in our experiment, it caused the Fe/Mn oxides-bound fraction of $\mathrm{Mn}$ in the soil to decrease, and the acid-soluble Mn to increase. 

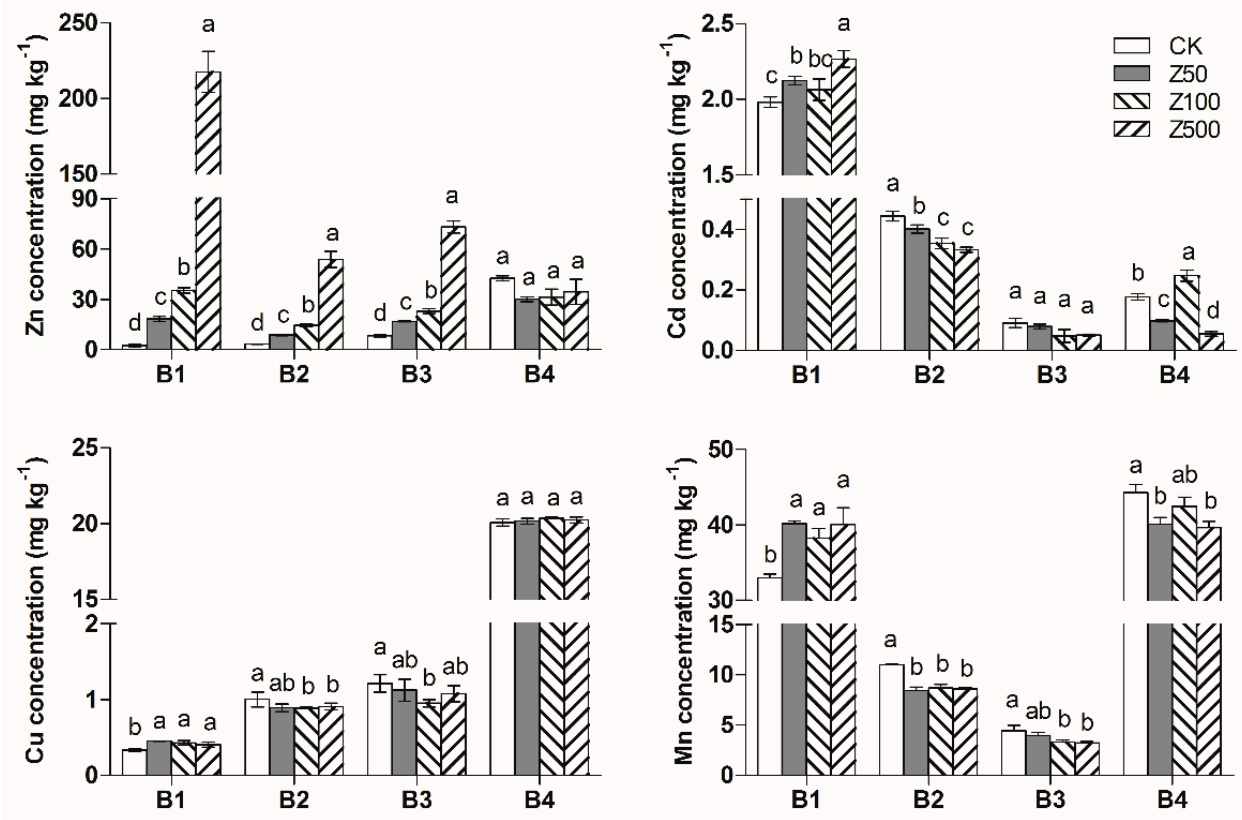

Figure 3. Changes in soil heavy metals chemical speciation with ZnO-NPs addition. B1: acid-soluble fraction; B2: Fe/Mn oxides-bound fraction; B3: organic-bound fraction; B4: residual fraction. Different letters above each column indicate significant difference $(p<0.05)$ between various treatments.

\subsection{3. $\mathrm{CuO}-\mathrm{NPs}$}

As shown in Figure 4, the addition of CuO-NPs had no significant effect on changes in $\mathrm{Zn}$ chemical speciation. The addition of CuO-NPs obviously increased the acid-soluble $\mathrm{Cd}$ and $\mathrm{Mn}$ concentrations and decreased the $\mathrm{Fe} / \mathrm{Mn}$ oxides-bound fraction of the $\mathrm{Cd}$ and $\mathrm{Mn}$ concentrations. The influence became more obvious as the $\mathrm{CuO}-\mathrm{NPs}$ concentration increased.
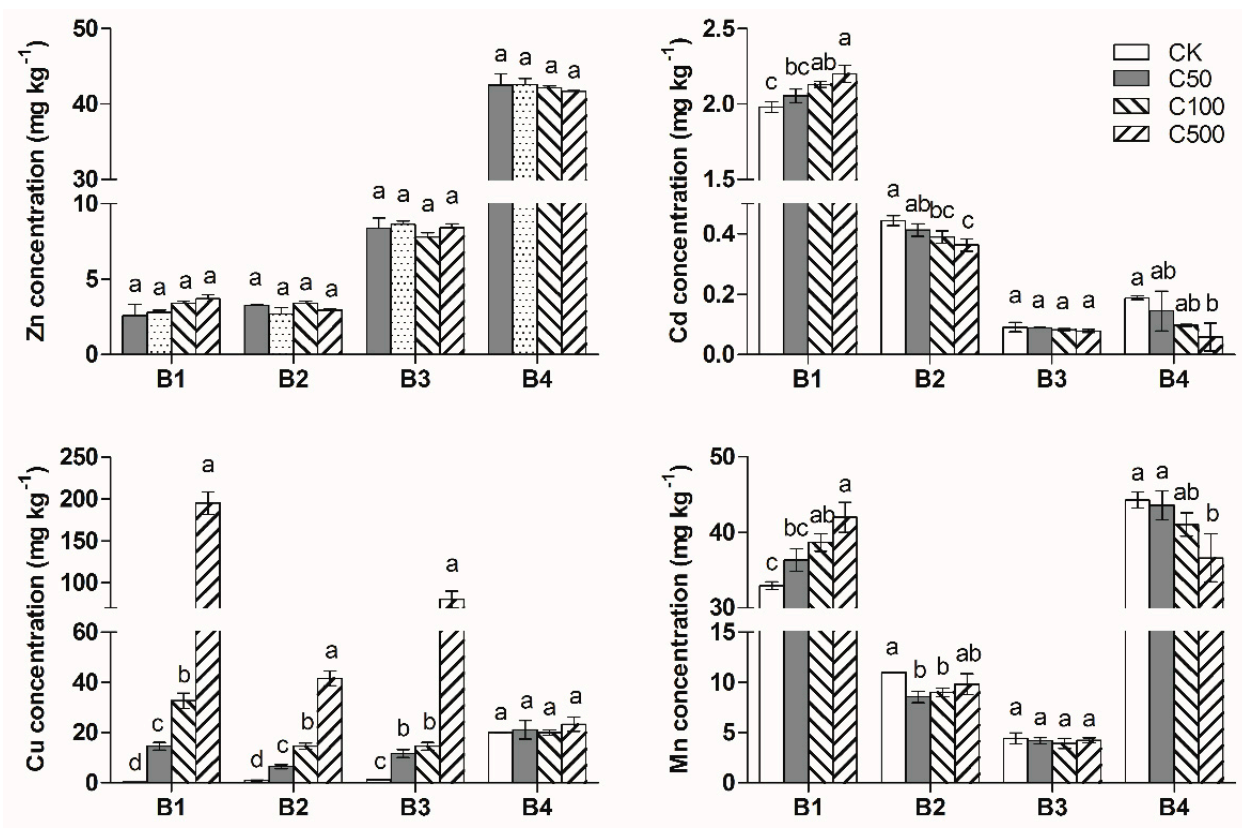

Figure 4. Changes in soil heavy metals chemical speciation with CuO-NPs addition. B1: acid-soluble fraction; B2: Fe/Mn oxides-bound fraction; B3: organic-bound fraction; B4: residual fraction. Different letters above each column indicate significant difference $(p<0.05)$ between various treatments.

For the $\mathrm{CuO}-\mathrm{NPs}$ treatment, significant increases in the acid-soluble fraction, $\mathrm{Fe} / \mathrm{Mn}$ oxides-bound fraction and organic-bound fraction of the $\mathrm{Cu}$ concentration were observed. The acid-soluble fraction 
of $\mathrm{Cu}$ increased by $14.7,32.7$ and $195 \mathrm{mg} \cdot \mathrm{kg}^{-1}$ compared to that of the control treatment for C50, C100 and $\mathrm{C} 500$, respectively. This outcome revealed that the CuO-NPs could dissolve in the soil and release ionic $\mathrm{Cu}$; after the 90-d experiment, approximately $35 \% \sim 48 \%$ of the $\mathrm{Cu}$ ions existed as the acid-soluble fraction, $10 \% \sim 18 \%$ of the $\mathrm{Cu}$ ions existed as the Fe/Mn oxides-bound fraction, and $20 \% \sim 29 \%$ of the $\mathrm{Cu}$ ions existed as the organic-bound fraction. For changes in $\mathrm{Cu}$ chemical speciation in the soil, the proportion of the acid-soluble fraction increased, while the proportion of $\mathrm{Fe} / \mathrm{Mn}$ oxides-bound fraction and organic-bound fraction decreased, in response to the increase in the CuO-NPs concentration.

Soil redox potential was one of the key factors influencing the heavy metal chemical speciation, the acid-soluble heavy metal concentrations in soil would increase under oxidation condition. In this research, the addition of CuO-NPs and ZnO-NPs increased the soil Eh, and then promoted the transformation of $\mathrm{Cd}$ and $\mathrm{Mn}$ from a $\mathrm{Fe} / \mathrm{Mn}$ oxides-bound fraction to an acid-soluble fraction. In addition, the adsorption of soil microorganisms on heavy metals was also an important factor influencing the heavy metal chemical speciation. Soil microorganisms could adsorb heavy metals and affect the mobility of heavy metals in the soil environment. Many studies have shown that the addition of nanoparticles in soil could affect soil microbial biomass and soil enzyme activities [23]. MNPs could influence the heavy metal chemical speciation by affecting the soil microorganisms. In this research, the changes of $\mathrm{Cd}$ and $\mathrm{Mn}$ chemical speciation may also be related with the change of soil microorganisms which is caused by the addition of CuO-NPs and ZnO-NPs.

After the 90-d flooding-drying process, more than half of the ZnO-NPs and CuO-NPs dissolved and released ionic $\mathrm{Zn}$ and $\mathrm{Cu}$ into the soil. The dissolution of $\mathrm{CuO}-\mathrm{NPs}$ and $\mathrm{ZnO}-\mathrm{NPs}$ clearly increased the $\mathrm{Cu}$ and $\mathrm{Zn}$ concentrations in the acid-soluble fraction, $\mathrm{Fe} / \mathrm{Mn}$ oxides-bound fraction and organic fraction but have no significant impact on the residual fraction. Total concentrations of $\mathrm{Zn}$ and $\mathrm{Cu}$ reached approximately $400 \mathrm{mg} \cdot \mathrm{kg}^{-1}$ in the maximum nanoparticle concentration treatments (500 $\left.\mathrm{mg} \cdot \mathrm{kg}^{-1}\right)$. Although the $\mathrm{Zn} / \mathrm{Cu}$ concentration did not exceed the threshold of the Chinese environmental quality standard for soils (GB15618-1995) $\left(500 \mathrm{mg} \cdot \mathrm{kg}^{-1}\right)$, there was a potential environmental risk as the MNPs' concentrations increased.

\subsection{Effect of MNPs Addition on Soil Cd and Micronutrient Bioavailability}

Two standard extraction methods $\left(\mathrm{CaCl}_{2}\right.$ and DTPA) were used to assess the change in soil $\mathrm{Cd}$ and micronutrient ( $\mathrm{Fe}, \mathrm{Mn}, \mathrm{Cu}, \mathrm{Zn}$ ) bioavailability after the addition of MNPs. As shown in Figure 5, the addition of $\mathrm{TiO}_{2}-\mathrm{NPs}$ clearly decreased the soil $\mathrm{Cd}$ bioavailability and the $\mathrm{Cd}$ concentration extracted by $\mathrm{CaCl}_{2}$ and DTPA, which decreased by $13.8 \% \sim 16.8 \%$ and $5.0 \% \sim 15.4 \%$, respectively, compared to that of the control treatment.
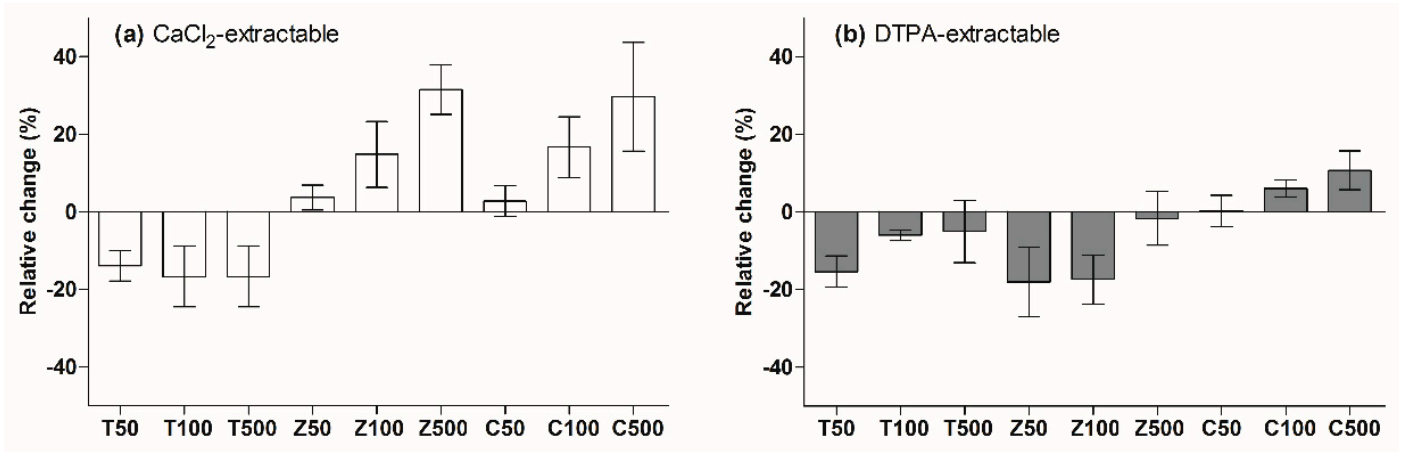

Figure 5. Relative change in soil Cd bioavailability after the addition of nanoparticles.

For the $\mathrm{ZnO}-\mathrm{NPs}$ treatment, the $\mathrm{CaCl}_{2}$-extractable $\mathrm{Cd}$ concentration increased by $3.7 \%$ 31.5\%, and the increase was proportional to the ZnO-NPs concentration. However, ZnO-NPs significantly decreased the DTPA-extractable Cd concentration. The addition of CuO-NPs caused significant increases in the soil $\mathrm{Cd}$ bioavailability, and the increase was in proportion to the CuO-NPs concentration. 
Compared with the control treatment, the $\mathrm{CaCl}_{2}$-extractable $\mathrm{Cd}$ concentration increased by $2.8 \% \sim 29.6 \%$, and the DTPA-extractable $\mathrm{Cd}$ concentration increased by $0.3 \% \sim 10.7 \%$.

The bioavailability of $\mathrm{Cd}$ in the soils increased in response to the increases in the $\mathrm{ZnO}-\mathrm{NPs} / \mathrm{CuO}-\mathrm{NPs}$ concentrations because the dissolution of the $\mathrm{ZnO}-\mathrm{NPs} / \mathrm{CuO}-\mathrm{NPs}$ released $\mathrm{Zn} / \mathrm{Cu}$ ions, and the competitive adsorption between $\mathrm{Zn} / \mathrm{Cu}$ and $\mathrm{Cd}$ reduced the adsorption capacity of $\mathrm{Cd}$ in the soil [32]. The $\mathrm{CaCl}_{2}$-extractable $\mathrm{Cd}$ had a significant correlation $(p<0.05)$ with acid-soluble $\mathrm{Cd}$ content in soil, which indicated that $\mathrm{CaCl}_{2}$ extraction was more suitable for the evaluation of the soil $\mathrm{Cd}$ bioavailability in this study.

Iron, manganese, copper and zinc are essential crop micronutrients. A deficiency may lead to reduced disease resistance and decreased crop yields [24,33]. However, at high concentrations, these elements can also be toxic to plants and the surrounding microbial communities [22,34,35]. As shown in Figure $6 \mathrm{a}, \mathrm{b}$, the influence of MNPs on $\mathrm{CaCl}_{2}$-extractable Fe and DTPA-extractable Fe was totally different. The MNPs addition caused a decrease of the $\mathrm{CaCl}_{2}$-extractable Fe concentration, but an increase of the DTPA-extractable Fe concentration.
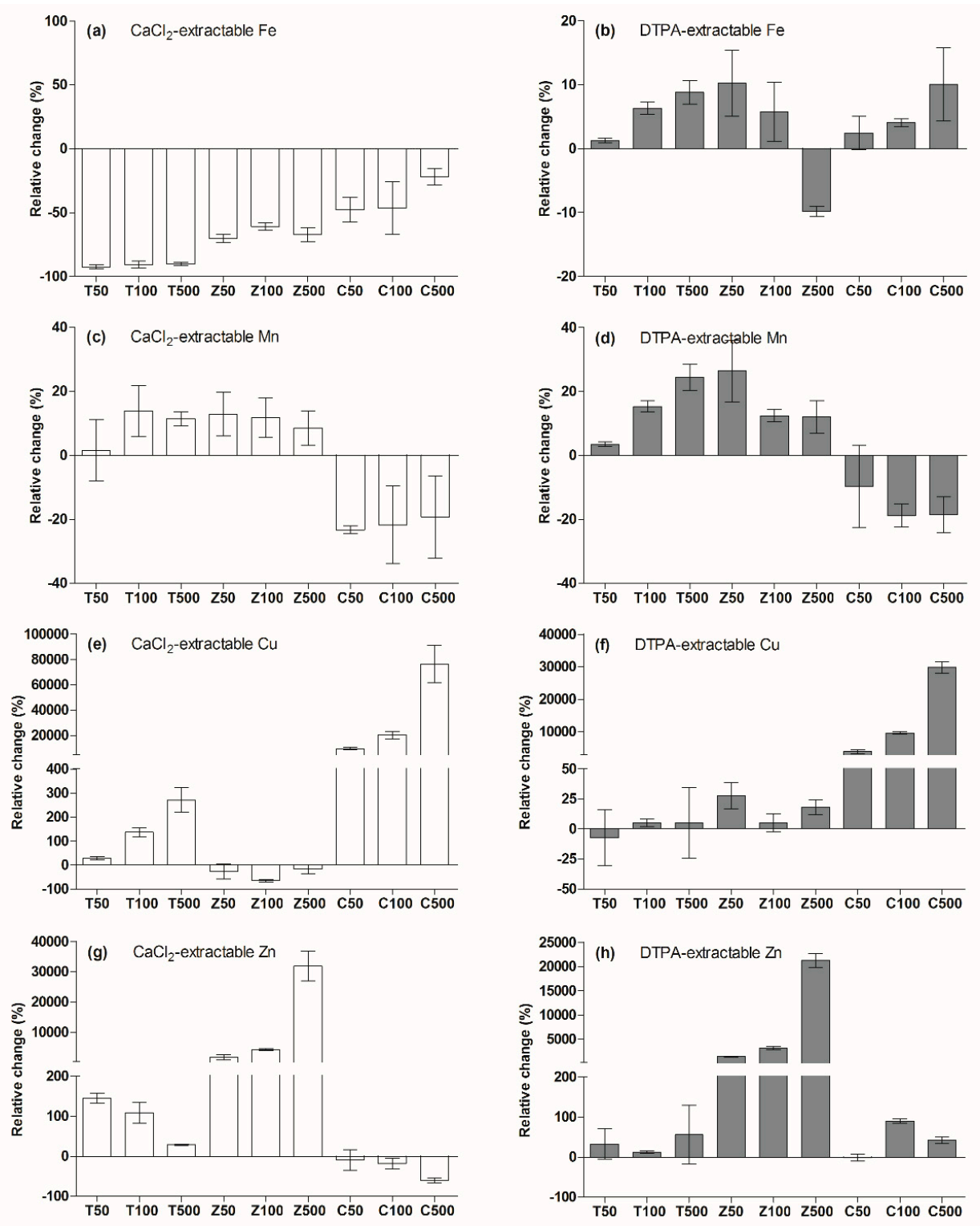

Figure 6. Relative change in soil micronutrient bioavailability after the addition of nanoparticles. 
Both the $\mathrm{TiO}_{2}$-NPs and $\mathrm{ZnO}-\mathrm{NPs}$ addition caused significant increases in Mn bioavailability. As shown in Figure $6 \mathrm{c}, \mathrm{d}$, in the T100 and T500 treatments, $\mathrm{CaCl}_{2}$-extractable $\mathrm{Mn}$ increased by $13.8 \%$ and $11.4 \%$, respectively, and DTPA-extractable Mn increased by $15.3 \%$ and $24.4 \%$, respectively. ZnO-NPs addition caused $\mathrm{CaCl}_{2}$-extractable Mn increased by $8.5 \% \sim 12.8 \%$, and DTPA-extractable Mn increased by $12.0 \% \sim 26.3 \%$. However, the addition of CuO-NPs reduced the soil Mn bioavailability compared with that of the control treatment, $\mathrm{CaCl}_{2}$-extractable Mn decreased by $19.3 \%$ 23.3\%, and DTPA-extractable Mn increased by $9.7 \% \sim 18.8 \%$.

For copper, with the increase in the $\mathrm{TiO}_{2}-\mathrm{NPs}$ concentration, the soil $\mathrm{CaCl}_{2}$-extractable $\mathrm{Cu}$ increased by $30 \% \sim 270 \%$ (Figure 6e). With the addition of $\mathrm{ZnO}-\mathrm{NPs}$, the $\mathrm{CaCl}_{2}$-extractable $\mathrm{Cu}$ decreased by 17.0\% 64.9\%, and DTPA-extractable $\mathrm{Cu}$ increased by 5.2\% 27.9\% (Figure 6f). CuO-NPs dissolved and released ionic $\mathrm{Cu}$ after addition to the soil. In the $\mathrm{C} 50, \mathrm{C} 100$ and $\mathrm{C} 500$ treatments, $\mathrm{CaCl}_{2}$-extractable $\mathrm{Cu}$ increased from $0.003 \mathrm{mg} \cdot \mathrm{kg}^{-1}$ to $0.32,0.68$ and $2.6 \mathrm{mg} \cdot \mathrm{kg}^{-1}$, respectively, and DTPA-extractable $\mathrm{Cu}$ increased from $0.05 \mathrm{mg} \cdot \mathrm{kg}^{-1}$ to $19.0,47.0$ and $145.3 \mathrm{mg} \cdot \mathrm{kg}^{-1}$, respectively.

$\mathrm{TiO}_{2}$-NPs addition obviously increased the soil $\mathrm{Zn}$ bioavailability, $\mathrm{CaCl}_{2}$-extractable $\mathrm{Zn}$ increased by $28.6 \% \sim 145.5 \%$, and DTPA-extractable $\mathrm{Zn}$ increased by $12.2 \% \sim 56.1 \%$ (Figure $6 \mathrm{~g}, \mathrm{~h}$ ). ZnO-NPs dissolved and released ionic $\mathrm{Zn}$ after the addition to the soil, and the increase in the $\mathrm{Zn}$ concentration was in proportion to the $\mathrm{ZnO}-\mathrm{NPs}$ concentration. In the $\mathrm{Z50}, \mathrm{Z100}$ and $\mathrm{Z} 500$ treatments, $\mathrm{CaCl}_{2}$-extractable $\mathrm{Zn}$ increased from $0.055 \mathrm{mg} \cdot \mathrm{kg}^{-1}$ to $0.98,2.4$ and $17.6 \mathrm{mg} \cdot \mathrm{kg}^{-1}$, respectively, and DTPA-extractable $\mathrm{Cu}$ increased from $0.9 \mathrm{mg} \cdot \mathrm{kg}^{-1}$ to $12.8,28.4$ and $184.6 \mathrm{mg} \cdot \mathrm{kg}^{-1}$, respectively. In the $\mathrm{C} 100$ and C500 treatments, $\mathrm{CaCl}_{2}$-extractable $\mathrm{Zn}$ decreased by $18.2 \%$ and $60.0 \%$, respectively, but in contrast, DTPA-extractable Zn increased by $90.2 \%$ and $42.2 \%$, respectively.

The effect of the MNPs on the heavy metal bioavailability of the soil depended on the soil properties, the dissolving capacity and diameter of the nanoparticles, the test conditions, etc. Adsorption studies have shown that MNPs affect the fate and transport of contaminants in aqueous conditions [36-38]. In this study, the results showed that these three MNPs exhibited different influences on the chemical speciation of heavy metals and micronutrient bioavailability in the soil. $\mathrm{TiO}_{2}-\mathrm{NPs}$ could affect the heavy metals and micronutrients bioavailability attributed to the special surface properties of nanoparticle, however, the effect of $\mathrm{ZnO}-\mathrm{NPs} / \mathrm{CuO}-\mathrm{NPs}$ was due to the $\mathrm{Zn}^{2+}$ and $\mathrm{Cu}^{2+}$ that released from the dissolution of the $\mathrm{ZnO}-\mathrm{NPs} / \mathrm{CuO}-\mathrm{NPs}$.

In soil conditions, nanoparticles may aggregate in the surface of the soil and have no significant impact on the surface area of soil [37]. On the other hand, heavy metals adsorbed in colloids could be transported with the colloids in soils, leading to higher mobility and bioavailability $[37,38]$, and the nanoparticles exhibited similar behaviour and effects in the environment compared to the colloids [39]. Thus, it is necessary to conduct further research on the environmental behaviour of nanoparticles in soil system.

\section{Conclusions}

In this study, the chemical speciation and bioavailability of heavy metals and micronutrients were observed. ZnO-NPs and CuO-NPs caused significant increases in the values of soil $\mathrm{pH}$ and EC after the 90-d flooding-drying process. ZnO-NPs and CuO-NPs addition caused clear increases in the $\mathrm{Zn}$ and $\mathrm{Cu}$ concentrations in the acid-soluble fraction, $\mathrm{Fe} / \mathrm{Mn}$ oxides-bound fraction and organic-bound fraction, leading to higher bioavailability in the soil. DTPA-extractable $\mathrm{Zn}$ and $\mathrm{Cu}$ increased to 184.6 $\mathrm{mg} \cdot \mathrm{kg}^{-1}$ and $145.3 \mathrm{mg} \cdot \mathrm{kg}^{-1}$, respectively, in the maximum ZnO-NPs and CuO-NPs concentration treatments $\left(500 \mathrm{mg} \cdot \mathrm{kg}^{-1}\right)$. These three MNPs exhibited different influences on soil micronutrient bioavailability. Soil Cd bioavailability was obviously decreased in the $\mathrm{TiO}_{2}-\mathrm{NPs}$ treatment but increased in the $\mathrm{ZnO}-\mathrm{NPs}$ and $\mathrm{CuO}-\mathrm{NPs}$ treatments. The addition of $\mathrm{TiO}_{2}-\mathrm{NPs}$ and $\mathrm{ZnO}-\mathrm{NPs}$ obviously increased soil Mn bioavailability, while the addition of CuO-NPs reduced soil Mn bioavailability. Further efforts are needed to investigate the environmental behaviour of nanoparticles in soil systems. 
Supplementary Materials: The following are available online at http://www.mdpi.com/1660-4601/17/7/2482/s1, Table S1: Basic physicochemical properties of paddy soils, Table S2: The recovery of $\mathrm{Cu}$ and $\mathrm{Zn}$ in the soils with $\mathrm{CuO}-\mathrm{NPs}$ and ZnO-NPs addition.

Author Contributions: Methodology, J.L. and X.Y.; software, M.Z.; data curation, J.L.; writing-original draft preparation, W.Z.; writing - review and editing, H.Z.; project administration, W.C.; funding acquisition, W.Z. and H.Z. All authors have read and agreed to the published version of the manuscript.

Funding: This research was funded by the Foundation for Innovative Research Groups of the National Natural Science Foundation of China, grant number 31621091, and the General Financial Grant from the China Postdoctoral Science Foundation, grant number 2017M620504.

Conflicts of Interest: The authors declare no conflict of interest.

\section{References}

1. Wang, Y.X.; Zhu, X.X.; Lao, Y.M.; Lv, X.H.; Tao, Y.; Huang, B.M.; Wang, J.X.; Zhou, J.; Cai, Z.H. TiO 2 nanoparticles in the marine environment: Physical effects responsible for the toxicity on algae Phaeodactylum tricornutum. Sci. Total Environ. 2016, 565, 818-826. [CrossRef] [PubMed]

2. Zhang, W.; Long, J.H.; Li, J.; Zhang, M.; Xiao, G.L.; Ye, X.Y.; Chang, W.J.; Zeng, H. Impact of ZnO nanoparticles on Cd toxicity and bioaccumulation in rice (Oryza sativa L.). Environ. Sci. Pollut. Res. 2019, 26, 23119-23128. [CrossRef] [PubMed]

3. Adeleye, A.S.; Conway, J.R.; Garner, K.; Huang, Y.; Su, Y.; Keller, A.A. Engineered nanomaterials for water treatment and remediation: Costs, benefits, and applicability. Chem. Eng. J. 2016, 286, 640-662. [CrossRef]

4. Gao, Y.; Yang, T.T.; Jin, J. Nanoparticle pollution and associated increasing potential risks on environment and human health: A case study of China. Environ. Sci. Pollut. Res. 2015, 22, 19297-19306. [CrossRef] [PubMed]

5. Shaw, A.K.; Hossain, Z. Impact of nano-CuO stress on rice (Oryza sativa L.) seedlings. Chemosphere 2013, 93, 906-915. [CrossRef] [PubMed]

6. Zhang, R.C.; Zhang, H.B.; Tu, C.; Hu, X.F.; Li, L.Z.; Luo, Y.M.; Christie, P. Phytotoxicity of ZnO nanoparticles and the released $\mathrm{Zn}$ (II) ion to corn (Zea mays L.) and cucumber (Cucumis sativus L.) during germination. Environ. Sci. Pollut. Res. 2015, 22, 11109-11117. [CrossRef]

7. Siddiqi, K.S.; Husen, A. Engineered gold nanoparticles and plant adaptation potential. Nanoscale Res. Lett. 2016, 11, 400. [CrossRef]

8. Yang, K.; Xing, B.S. Adsorption of organic compounds by carbon nanomaterials in aqueous phase: Polanyi theory and its application. Cheminform 2010, 110, 5989-6008.

9. Ahsan, M.A.; Jabbari, V.; Imam, M.A.; Castro, E.; Kim, H.; Curry, M.L.; Valles-Rosales, D.J.; Noveron, J.C. Nanoscale nickel metal organic framework decorated over graphene oxide and carbon nanotubes for water remediation. Sci. Total Environ. 2020, 698, 134214. [CrossRef]

10. Ahsan, M.A.; Fernandez-Delgado, O.; Deemer, E.; Wang, H.Y.; El-Gendy, A.A.; Curry, M.L.; Noveron, J.C. Carbonization of Co-BDC MOF results in magnetic C@Co nanoparticles that catalyze the reduction of methyl orange and 4-nitrophenol in water. J. Mol. Liq. 2019, 290, 111059. [CrossRef]

11. Shrestha, B.; Anderson, T.A.; Acosta-Martinez, V.; Payton, P.; Cañas-Carrell, J.E. The influence of multiwalled carbon nanotubes on polycyclic aromatic hydrocarbon (pah) bioavailability and toxicity to soil microbial communities in alfalfa rhizosphere. Ecotoxicol. Environ. Saf. 2015, 116, 143-149. [CrossRef] [PubMed]

12. Tafazoli, M.; Hojjati, S.M.; Biparva, P.; Kooch, Y.; Lamersdorf, N. Reduction of soil heavy metal bioavailability by nanoparticles and cellulosic wastes improved the biomass of tree seedlings. J. Plant Nutr. Soil Sci. 2017, 180, 683-693. [CrossRef]

13. Zhao, X.; Liu, W.; Cai, Z.Q.; Han, B.; Qian, T.W.; Zhao, D.Y. An overview of preparation and applications of stabilized zero-valent iron nanoparticles for soil and groundwater remediation. Water Res. 2016, 100, 245-266. [CrossRef] [PubMed]

14. Hu, X.G.; Kang, J.; Lu, K.C.; Zhou, R.R.; Mu, L.; Zhou, Q.X. Graphene oxide amplifies the phytotoxicity of arsenic in wheat. Sci. Rep. 2014, 4, 6122. [CrossRef] [PubMed]

15. Ma, C.; Liu, H.; Chen, G.C.; Zhao, Q.; Eitzer, B.; Wang, Z.H.; Cai, W.J.; Newman, L.; White, J.C.; Dhankher, O.P.; et al. Effects of titanium oxide nanoparticles on tetracycline accumulation and toxicity in Oryza sativa (L.). Environ. Sci. Nano 2017, 4, 1827-1839. [CrossRef] 
16. Servin, A.D.; White, J.C. Nanotechnology in agriculture: Next steps for understanding engineered nanoparticle exposure and risk. Nanoimpact 2016, 1, 9-12. [CrossRef]

17. Ahsan, M.A.; Jabbari, V.; El-Gendy, A.A.; Curry, M.L.; Noveron, J.C. Ultrafast catalytic reduction of environmental pollutants in water via MOF-derived magnetic $\mathrm{Ni}$ and $\mathrm{Cu}$ nanoparticles encapsulated in porous carbon. Appl. Surf. Sci. 2019, 497, 143608. [CrossRef]

18. Ahsan, M.A.; Deemer, E.; Fernandez-Delgado, O.; Wang, H.Y.; Curry, M.L.; El-Gendy, A.A.; Noveron, J.C. Fe nanoparticles encapsulated in MOF-derived carbon for the reduction of 4-nitrophenol and methyl orange in water. Catal. Commun. 2019, 130, 105753. [CrossRef]

19. Franklin, N.M.; Rogers, N.J.; Apte, S.C.; Batley, G.E.; Gadd, G.E.; Casey, P.S. Comparative toxicity of nanoparticulate $\mathrm{ZnO}$, bulk $\mathrm{ZnO}$, and $\mathrm{ZnCl}_{2}$ to a freshwater microalga (Pseudokirchneriella subcapitata): The importance of particle solubility. Environ. Sci. Technol. 2007, 41, 8484-8490. [CrossRef]

20. Adams, J.; Wright, M.; Wagner, H.; Valiente, J.; Britt, D.; Anderson, A. Cu from dissolution of CuO nanoparticles signals changes in root morphology. Plant Physiol. Biochem. 2017, 110, 108-117. [CrossRef]

21. Qiu, H.; Smolders, E. Nanospecific phytotoxicity of $\mathrm{CuO}$ nanoparticles in soils disappeared when bioavailability factors were considered. Environ. Sci. Technol. 2017, 51, 11976-11985. [CrossRef] [PubMed]

22. Gao, X.Y.; Avellan, A.; Laughton, S.N.; Vaidya, R.; Rodrigues, S.M.; Casman, E.A.; Lowry, G.V. CuO nanoparticle dissolution and toxicity to wheat (Triticum aestivum) in rhizosphere soil. Environ. Sci. Technol. 2018, 52, 2888-2897. [CrossRef] [PubMed]

23. Xu, C.; Peng, C.; Sun, L.J.; Zhang, S.; Huang, H.M.; Chen, Y.X.; Shi, J.Y. Distinctive effects of TiO 2 , and CuO nanoparticles on soil microbes and their community structures in flooded paddy soil. Soil Biol. Biochem. 2015, 86, 24-33. [CrossRef]

24. Nemati, K.; Abu Bakar, N.K.; Abas, M.R.; Sobhanzadeh, E. Speciation of heavy metals by modified BCR sequential extraction procedure in different depths of sediments from Sungai Buloh, Selangor, Malaysia. J. Hazard. Mater. 2011, 192, 402-410. [CrossRef]

25. Shi, J.Y.; Ye, J.E.; Fang, H.X.; Zhang, S.; Xu, C. Effects of copper oxide nanoparticles on paddy soil properties and components. Nanomaterials 2018, 8, 839. [CrossRef]

26. Simonin, M.; Richaume, A. Impact of engineered nanoparticles on the activity, abundance, and diversity of soil microbial communities: A review. Environ. Sci. Pollut. Res. Int. 2015, 22, 13710-13723. [CrossRef]

27. Liu, S.J.; Wei, H.M.; Li, Z.Y.; Li, S.; Yan, H.; He, Y.; Tian, Z.H. Effects of graphene on germination and seedling morphology in rice. J. Nanosci. Nanotechnol. 2015, 15, 2695-2701. [CrossRef]

28. Ben-Moshe, T.; Frenk, S.; Dror, I.; Minz, D.; Berkowitz, B. Effects of metal oxide nanoparticles on soil properties. Chemosphere 2013, 90, 640-646. [CrossRef]

29. Cullen, L.G.; Tilston, E.L.; Mitchell, G.R.; Collins, C.D.; Shaw, L.J. Assessing the impact of nano- and micro-scale zerovalent iron particles on soil microbial activities: Particle reactivity interferes with assay conditions and interpretation of genuine microbial effects. Chemosphere 2011, 82, 1675-1682. [CrossRef]

30. Frenk, S.; Ben-Moshe, T.; Dror, I.; Berkowitz, B.; Minz, D. Effect of metal oxide nanoparticles on microbial community structure and function in two different soil types. PLoS ONE 2013, 8, e84441. [CrossRef]

31. Peng, C.; Xu, C.; Liu, Q.L.; Sun, L.J.; Luo, Y.M.; Shi, J.Y. Fate and transformation of CuO nanoparticles in the soil-rice system during the life cycle of rice plants. Environ. Sci. Technol. 2017, 51, 4907-4917. [CrossRef] [PubMed]

32. Lin, Q.; Xu, S.H. A review on competitive adsorption of heavy metals in soils. Soils 2008, 40, 706-711.

33. Rizwan, M.; Ali, S.; Qayyum, M.F.; Yong, S.O.; Adrees, M.; Ibrahim, M.; Zia-ur-Rehman, M.; Farid, M.; Abbas, F. Effect of metal and metal oxide nanoparticles on growth and physiology of globally important food crops: A critical review. J. Hazard. Mater. 2016, 322, 2-16. [CrossRef] [PubMed]

34. Du, W.C.; Sun, Y.Y.; Ji, R.; Zhu, J.G.; Wu, J.C.; Guo, H.Y. $\mathrm{TiO}_{2}$ and $\mathrm{ZnO}$ nanoparticles negatively affect wheat growth and soil enzyme activities in agricultural soil. J. Environ. Monit. 2011, 13, 822-828. [CrossRef]

35. Ge, Y.; Schimel, J.P.; Holden, P.A. Evidence for negative effects of $\mathrm{TiO}_{2}$ and $\mathrm{ZnO}$ nanoparticles on soil bacterial communities. Environ. Sci. Technol. 2011, 45, 1659-1664. [CrossRef]

36. Zhang, M.; He, F.; Zhao, D.Y.; Hao, X.D. Degradation of soil-sorbed trichloroethylene by stabilized zero valent iron nanoparticles: Effects of sorption, surfactants, and natural organic matter. Water Res. 2011, 45, 2401-2414. [CrossRef]

37. Ling, W.T.; Xu, J.M.; Gao, Y.Z. Dissolved organic matter enhances the sorption of atrazine by soil. Biol. Fertil. Soils 2006, 42, 418-425. [CrossRef] 
38. Bin, G.; Cao, X.D.; Dong, Y.; Luo, Y.M.; Ma, L.Q. Colloid deposition and release in soils and their association with heavy metals. Crit. Rev. Environ. Sci. Technol. 2011, 41, 336-372. [CrossRef]

39. Nowack, B.; Bucheli, T.D. Occurrence, behavior and effects of nanoparticles in the environment. Environ. Pollut. 2007, 150, 5-22. [CrossRef]

(C) 2020 by the authors. Licensee MDPI, Basel, Switzerland. This article is an open access article distributed under the terms and conditions of the Creative Commons Attribution (CC BY) license (http://creativecommons.org/licenses/by/4.0/). 